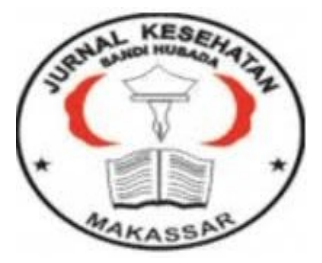

\author{
Jurnal Ilmiah Kesehatan Sandi Husada \\ hhttps://akper-sandikarsa.e-journal.id/JIKSH \\ Vol 11, No, 1, Juni 2020, pp;430-440 \\ p-ISSN: 2354-6093 dan e-ISSN: 2654-4563 \\ DOI: $10.35816 /$ jiskh.v10i2.319
}

\title{
Efektivitas Antibakteri Campuran Nanokitosan 1\% dengan Berbagai Konsentrasi Ekstrak Biji Kelengkeng Terhadap Staphylococcus Aureus
}

Comparison of Antibacterial Effectiveness of Nanochitosan 1\% Mixture with Various Concentrations of Longan Seed Extract against Staphylococcus Aureus

Sabrina Khairunnisa1, Titania Aurelya Tandra², Mellisa Sim ${ }^{3}$, Florenly

12 Pendidikan Dokter Gigi, Fakultas Kedokteran Gigi, Universitas Prima Indonesia 3 4Fakultas Kedokteran Gigi, Universitas Prima Indonesia

\section{Artikel info}

Artikel history:

Received; 20 April 2020

Revised: 20 Mei 2020

Accepted; 23 Mei 2020

\begin{abstract}
As shown on the qualitative phytochemical examinations, longan seeds contains bioactive compounds of flavonoids, glycosides, saponins and tannins, hence it has antibacterial potential. Whereas nanochitosan, besides having antibacterial activity, is used as a matrix for various types of drugs and plant extracts. This study aims to compare the effectiveness of nanochitosan 1\% mix with longan seed extract in inhibiting the growth of Staphylococcus aureus, between $80 \%, 60 \%$ and $40 \%$ concentration. Longan seed extract was prepared using maceration method and made into various concentration, i.e. $80 \%, 60 \%$ and $40 \%$. The nanochitosan $1 \%$ was prepared with ionic gelation method. The two ingredients were mixed in a ratio of 1: 1 . The antibacterial investigations on the different concentration utilized the disk diffusion method. The results presented the mean inhibition power of a mixture of $80 \%$ concentration was $9.38 \mathrm{~mm}$; concentration of $60 \%(8.47 \mathrm{~mm})$ and concentration of $40 \%$ (7.10 mm). Statistical analysis using one way ANOVA showed the most effective concentration of mixture in inhibiting Staphylococcus aureus was seen at 80\%, where $p=$ 0,000 ( $p$ <0.05). The results of this study indicate that increasing the concentration of longan seed extract strengthens the inhibitory power against Staphylococcus aureus. The outcome was justified as the increment in concentration of longan seed extracts lead to increase in the quantity of active compounds, thereby upsurge its effectiveness in damaging Staphylococcus aureus cells.
\end{abstract}

Abstrak. Uji fitokimia kualitatif menunjukkan biji kelengkeng mengandung senyawa bioaktif flavonoid, glikosida, saponin dan tanin, sehingga berpotensi sebagai antibakteri. Sedangkan nanokitosan, selain memiliki aktivitas antibakteri, 
dapat juga dijadikan penghantar obat-obatan dan ekstrak tanaman. Penelitian ini bertujuan membandingkan perbedaan efektivitas campuran nanokitosan 1\% dengan ekstrak biji kelengkeng konsentrasi 80\%, 60\%, 40\% dalam menghambat pertumbuhan bakteri Staphylococcus aureus. Pembuatan ekstrak biji kelengkeng dilakukan dengan metode maserasi dan dibuat dalam konsentrasi 80\%, 60\%, 40\%. Adapun nanokitosan 1\% dibuat dengan metode gelasi ionik. Kedua bahan tersebut dicampurkan dengan perbandingan 1:1. Uji antibakteri terhadap campuran ekstrak dan nanokitosan tersebut menggunakan metode difusi cakram. Hasil penelitian menunjukkan mean daya hambat dari campuran konsentrasi $80 \%$ adalah $9.38 \mathrm{~mm}$; konsentrasi $60 \%(8,47 \mathrm{~mm})$ dan konsentrasi $40 \%(7,10 \mathrm{~mm})$. Uji statistik one way ANOVA menunjukkan bahwa campuran yang paling efektif dalam menghambat Staphylococcus aureus terlihat pada konsentrasi 80\% dibandingkan konsentrasi 60\% maupun $40 \%$, dimana $p=0.000(p<0.05)$. Hasil penelitian ini menunjukkan pertambahan konsentrasi ekstrak biji kelengkeng meningkatkan daya hambat terhadap Staphylococcus aureus. Hal ini disebabkan oleh adanya peningkatan jumlah kandungan senyawa aktif dari ekstrak biji kelengkeng seiring dengan pertambahan konsentrasi sehingga meningkatkan efektivitasnya dalam merusak sel Staphylococcus aureus.

\begin{tabular}{lr}
\hline Keywords: & $\begin{array}{r}\text { Coresponden author: } \\
\text { Biji Kelengkeng; }\end{array}$ \\
Nanokitosan; & Email: $\begin{array}{l}\text { sabrinaichaa@gmail.com } \\
\text { Staphylococcus }\end{array}$ \\
Aureus & artikel dengan akses terbuka dibawah lisensi BCC BY NC ND-4.0 \\
\hline
\end{tabular}

\section{Pendahuluan}

SKRT dalam Kemenkes RI pada tahun 2013 mengemukakan penyakit gigi dan mulut berada pada peringkat 6 yang menjadi suatu permasalahan umum penduduk Indonesia (Herlinawati, 2018). Menurut penelitian Yamin (2014) sebesar 50,73\% bakteri gram positif penyebab penyakit gigi dan mulut seperti abses ditemukan pada daerah akar gigi yang sudah tidak vital. Dari beberapa jenis bakteri gram positif yang diketahui pada rongga mulut, Staphylococcus aureus merupakan salah satu bakteri penyebab penyakit rongga mulut tersebut (Apridamayanti, 2017). Banyaknya kasus resistensi terhadap Staphylococcus aureus yang menjadi masalah dan perlu diperhatikan (Panuluh, 2019). Pemberian obat yang tidak rasional semakin meningkatkan resistensi bakteri ini terhadap berbagai jenis antibiotik. Penelitian menyatakan antibitotik golongan penisilin sangat resisten pada bakteri Staphylococcus epidermis, Staphylococcus aureus dan Staphylococcus hemolyticus (Marhamah, 2016).

Penelitian dengan bahan tanaman dapat dilakukan dalam mengembangkan alternatif untuk menghambat dan membunuh bakteri (Ngajow et al., 2013). Pada penelitian Lumbessy (2013) terbukti tanaman memilki banyak kandungan senyawa aktif yang dapat dimanfaatkan, seperti flavonoid yang ditemukan pada berbagai tanaman. Tanaman yang terbukti memiliki efektivitas antibakteri karna kandungan senyawanya adalah kelengkeng 
(Dimocarpus longan Lour) (Prasetya et al., 2019). Penelitian yang dilakukan Ripa (2010) membuktikan tanaman kelengkeng dapat dimanfaatkan karna memiliki golongan senyawa aktif di bagian kulit dan bijinya.

Terdapat senyawa fenolik pada bagian kulit dan biji kelengkeng yang berguna melindungi sel dari kerusakan oksidatif, serta menghambat pertumbuhan ragi, jamur, virus dan bakteri. Biji kelengkeng mengandung turunan tanin, asam galat dan asam ellagalat turunan senyawa fenolik serta flavonoid dan polisakarida. Senyawa tersebut memiliki aktifitas anti-inflamasi, antimutagenik, antikanker dan antioksidan pada biji kelengkeng (Soong et al., 2005; Tseng, 2014). Kulit buah kelengkeng juga mengandung antioksidan dan mampu melindungi ginjal dari toksisitas logam berat (Florenly et al., 2016).

Penelitian dari Prakash (2014) memperkuat hipotesa dimana dinyatakan bahwa ekstrak etanol $80 \%$ biji kelengkeng paling efektif dibandingkan konsentrasi 100\%, 60\%, 50\%, $40 \%$ dan $20 \%$ untuk pengekstrakan kandungan quercetin. Pada penelitian Prasetya (2019) fraksi etil asetat menggunakan ekstrak etanol biji kelengkeng konsentrasi 100000 ppm memiliki aktivitas penghambatan biofilm tertinggi pada bakteri Staphylococcus aureus dengan penghambatan pembentukan biofilm sebesar 99,08\%.

Penelitian lain yang dilakukan Tseng (2014) fraksi ekstrak metanol biji kelengkeng memiliki aktivitas antibakteri terhadap Propionibacterium acne, Streptococcus mutans, Staphylococcus aureus, dan MRSA. Meningkatnya konsentrasi ekstrak menyebabkan tingginya senyawa polyphenolic dalam menghambat bakteri-bakteri tersebut. Selain kandungan senyawa fitokimia, buah kelengkeng juga memiliki komponen kimia sebagai bahan biosorben, dimana daya adsorpsi logam berat dari biji kelengkeng lebih bagus dibandingkan kulitnya (Florenly et al., 2015).

Biomaterial alam lain sebagai alternatif pengobatan yang memiliki aktivitas antibakteri adalah kitosan yang di ekstraksi dari cangkang hewan laut seperti rajungan dan udang. Kitosan merupakan bahan bioaktif yang punya banyak kelebihan terutama penggunaannya sebagai penghantaran obat (Mohanraj et al., 2006). Penelitian Damayanti (2016) membuktikan kitosan konsentrasi 1\%, 2\%, dan 3\% dapat digunakan untuk menghambat bakteri seperti Escherichia coli, Staphylococcus aureus dan Bacillus subtilis yang berada di filet ikan patin.

Banyak ahli saat ini mengolah kitosan dengan nanoteknologi dan menghasilkan substansi yang disebut dengan nanokitosan. Nanokitosan mempunyai daya serap dan kemampuan antibakteri serta antijamur yang lebih baik daripada kitosan. Selain itu, nanokitosan mempunyai sifat yang tidak beracun, tidak mudah berubah ketika digunakan, tingginya luas permukaan dan juga bisa digunakan sebagai penghantar beragam jenis obat-obatan serta pengekstrakan tanaman (Berger et al., 2004).

Penelitian yang dilakukan Qudsi (2015) menggunakan konsentrasi nanokitosan 1\%, 0,5\%, 0,25\%, 0,125\%, dan 0,0625\% dalam menghambat bakteri Enterococcus faecalis menunjukkan nanokitosan memiliki daya hambat berbeda dalam setiap konsentrasi tetapi zona hambatan terbesar ditunjukkan pada konsentrasi $1 \%$. Banyak penelitian yang telah dilakukan dalam membuat alternatif dari bahan-bahan alami yang mengandung senyawa aktif untuk menghambat bakteri. Namun penelitian-penelitian yang telah dilakukan masih terbatas pada ekstrak biji kelengkeng atau nanokitosan secara terpisah. 


\section{Metode}

Jenis penelitian ini menggunakan penelitian eksperimen dalam laboratorium secara in vitro, dilakukan penelitian post test only control group design yaitu dengan observasi setelah perlakuan diberikan. Sampel buah kelengkeng segar diperoleh dari perkebunan PTPN III Lubuk Pakam dan di identifikasi jenisnya di Herbarium Medanese USU. Delapan ratus gram sampel biji buah kelengkeng ditumbuk dengan lumpang dan diblender sehingga halus, kemudian dikeringkan dengan microwave. Ekstraksi dilakukan dengan metode maserasi menggunakan etanol 95\% lalu di aduk setiap 24 jam selama 5 hari. Penyaringan dengan kertas saring dan bantuan pompa vakum. Filtrat yang terkumpul dimasukkan kedalam rotary evaporator. Kemudian diuapkan dengan beaker glass di dalam inkubator untuk mendapatkan ekstrak pekat biji kelengkeng. Ekstrak pekat dibuat menjadi tiga konsentrasi yaitu 80\%, 60\% dan 40\% dengan DMSO. Ekstrak pekat biji kelengkeng di uji fitokimia dengan metode skrinning untuk menentukan senyawa bioaktif pada ekstrak etanol biji kelengkeng yaitu uji alkaloid, flavonoid, triterpen/steroid, saponin, tanin dan glikosida (Nugraha et al., 2017).

Pembuatan nanokitosan menggunakan metode gelasi ionik. Bubuk kitosan sebanyak 0,2 g dicairkan kedalam $10 \mathrm{~mL}$ asam asetat 1\% dengan magnetic stirrer selama 8 jam, lalu disonikasi selama 40 menit. Natrium tripolifosfat 0,1 g dicairkan kedalam $100 \mathrm{~mL}$ akuades dengan perlakuan yang sama. Larutan natrium tripolifosfat $0,1 \%$ dicampurkan dengan larutan kitosan 1\% dengan perbandingan 2 : 1 menggunakan spuit $1 \mathrm{~mL}$ dengan kecepatan penetesan 15 tetes/menit, kemudian di stirrer selama 8 jam dan disonikasi selama 45 menit. Sampel larutan nanokitosan dianalisis ukurannya dengan menggunakan alat PSA (Particle Size Analysis) dengan alat dan metode yang berbeda yaitu Dynamic light scattering dan dispersi larutan di dua laboratorium yang berbeda. (Bangun et al., 2018). Pencampuran larutan nanokitosan 1\% kedalam tiap konsentrasi 80\%, 60\%, 40\% ekstrak biji kelengkeng dengan perbandingan campuran larutan nanokitosan dengan tiap konsentrasi yaitu 1 : 1 (Rismana et al., 2014).

Alat disterilisasi, kemudian dilakukan uji pertumbuhan bakteri menggunakan metode difusi cakram. Bakteri Staphylococcus aureus diremajakan dan disebarkan pada media agar dengan kapas pengulas yang steril. Cakram kertas disusun pada bagian atas permukaan media dengan letak yang sesuai. Peneliti membuat cakram kertas yg di tetesin ekstrak biji kelengkeng 80\%,60\%, 40\% dan nanokitosan 1\% dengan mikropipet, lalu media-media tersebut diletakkan ke dalam suhu $37^{\circ} \mathrm{C}$ pada inkubator dengan dengan waktu 24 jam. Prosedur tersebut diulangi sebanyak 6 kali pada setiap sampel. Pengukuran diameter zona hambat dengan colony counter dan jangka sorong pada media agar dilakukan oleh peneliti (Sari et al., 2017).

Uji normalitas Shapiro-Wilk, data yang terdistribusi normal diuji parametrik one way ANOVA untuk menganalisis signifikasi sehingga peneliti dapat mengetahui perbedaan rata-rata antara grup perlakuan (Ramadhani et al., 2017) 


\section{Hasil Dan Pembahasan}

Hasil identifikasi sampel biji kelengkeng pada penelitian ini didapatkan kelengkeng dari :

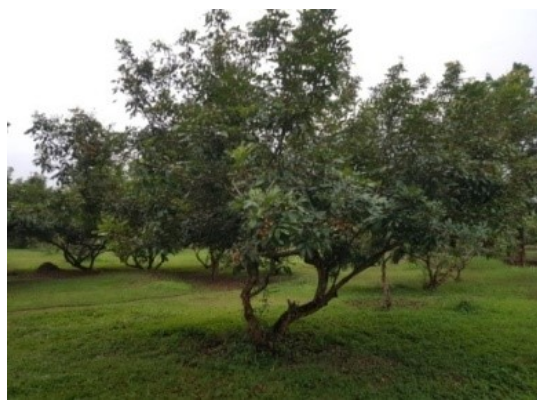

Gambar 1. Pohon Kelengkeng (Dimocarpus longan Lour)

$\begin{array}{lll}\text { Kingdom } & : & \text { Plantae } \\ \text { Divisi } & : & \text { Spermatophyta } \\ \text { Kelas } & : & \text { Dicotyledoneae } \\ \text { Ordo } & : & \text { Sapindales } \\ \text { Famili } & : & \text { Sapindaceae } \\ \text { Genus } & : & \text { Dimocarpus } \\ \text { Spesies } & : & \text { Dimocarpus longan Lour } \\ \text { Nama Lokal } & : & \text { Kelengkeng }\end{array}$

Hasil uji skrinning fitokimia diperoleh ekstrak biji kelengkeng pada penelitian ini positif mengandung golongan senyawa flavonoid, glikosida, saponin, dan tannin (Tabel 1). Pada penelitian Parubak (2013) menyatakan bahwa flavonoid adalah jenis senyawa polifenol yang dapat mencegah radikal bebas, tumor, radang dan mencegah pertumbuhan bakteri serta virus. Senyawa glikosida memiliki fungsi sebagai antibakteri, antikanker dan imunostimulan (Nonci et al., 2015). Saponin terdiri dari saponin steroid dan saponin triterpenoid yang memiliki fungsi sebagai antimikroba. Tanin berfungsi sebagai antioksidan, antiviral, anti-inflamasi, anti-HIV, antitumor dan antibakteri (Wau et al., 2019; Prasad et al., 2009). Menurut Soong (2006) pada biji kelengkeng terdapat senyawa polifenol seperti asam gallic, corilagin, asam chebulinic, asam chebulagic, asam ellagic, minyak atsiri. Fungsi dari senyawa polifenol sebagai antioksidan, antikanker, antibakteri dan menghambat pertumbuhan jamur. Penelitian lain yang dilakukan oleh Rangkadilok (2012) mengatakan bahwa golongan senyawa pada biji kelengkeng dapat dimanfaatkan dalam menghambat bakteri dan jamur.

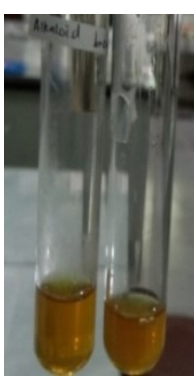

a

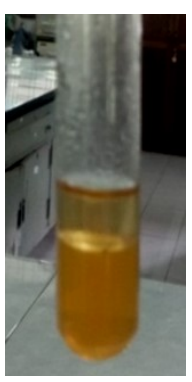

$\mathrm{b}$

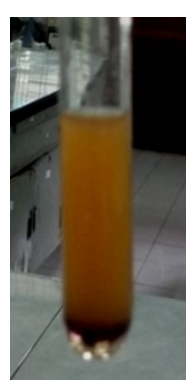

C

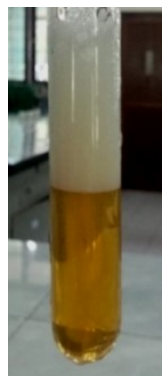

d

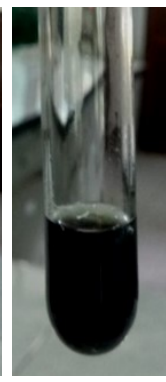

e

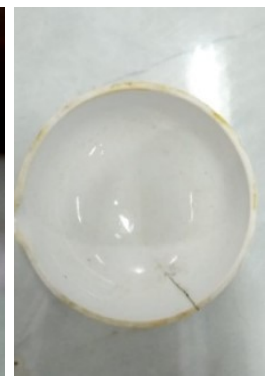

f

Gambar 2. Hasil Skrinning Fitokimia

Keterangan :
a. Alkaloid
d. Saponin
b. Flavonoid
e. Tanin
c. Glikosida
f. Triterpen/Steroid 
Tabel 1. Golongan senyawa ekstrak biji kelengkeng

\begin{tabular}{|c|c|c|c|c|c|c|}
\hline Nama Sampel & Alkaloid & Flavonoid & Glikosida & Saponin & Tanin & $\begin{array}{c}\text { Triterpen/ } \\
\text { Steroid }\end{array}$ \\
\hline Biji Kelengkeng & - & + & + & + & + & - \\
\hline
\end{tabular}

Sumber : Data primer, 2020

Ket: $\quad+=$ Positif

- = Negatif

Penelitian ini juga menggunakan nanokitosan dengan dua kali pengujian untuk memastikan ukuran partikel nanokitosan. Uji PSA (Particle Size Analysis) yang pertama menggunakan alat PSA (Horiba SZ-100) dengan metode Dynamic light scattering menunjukkan ukuran partikel 101,8 nm. Kemudian, uji PSA kedua menggunakan Analysette 22 NanoTec dengan metode dispersi larutan menunjukkan ukuran partikel 93,71 nm. Ukuran nanokitosan tersebut sesuai dengan penelitian Rachmawati (2018) yang menyatakan nanopartikel berukuran kisaran 10-1000 nm. Pernyataan ini diperkuat oleh penelitian Gupta (2006) bahwa ukuran nanopartikel yang menjadi dasar matriks obat adalah 50-300 nm. Pada penelitian Dustgania (2008), nanokitosan berukuran 250-350 nm dijadikan penghantar deksametason natrium fosfat agar masuk keperedaran darah dengan cepat. Penelitian lain yang dilakukan Putri (2018) didapatkan nano partikel kitosan dengan ekstrak daun ubi jalar putih ungu berukuran 302,6 nm.

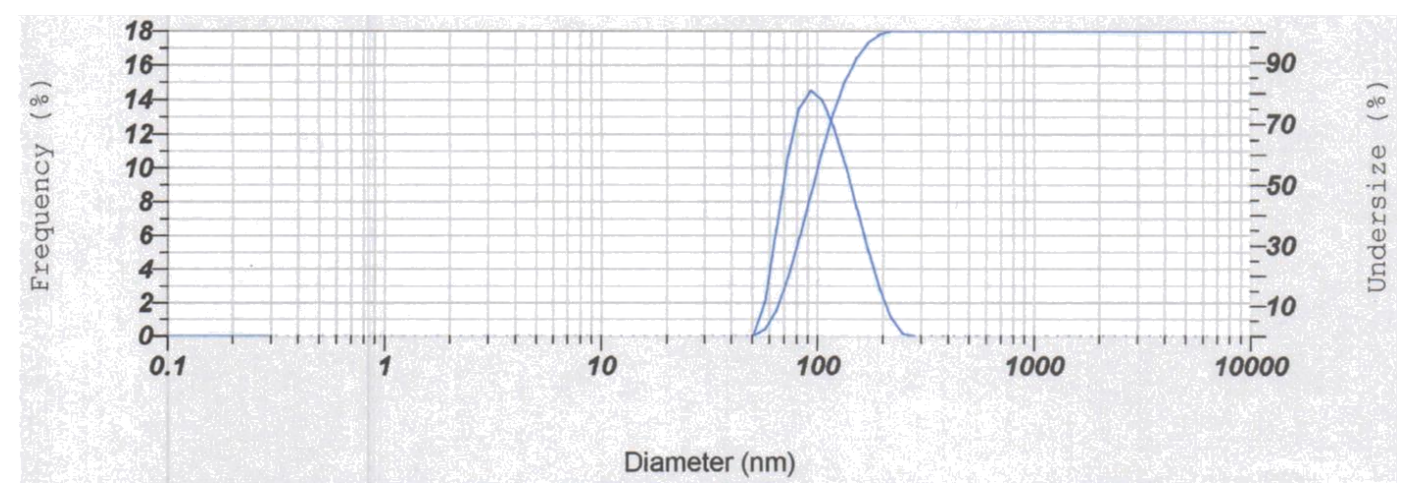

Gambar 3. Grafik Hasil Ukuran Nanokitosan Horiba SZ-100

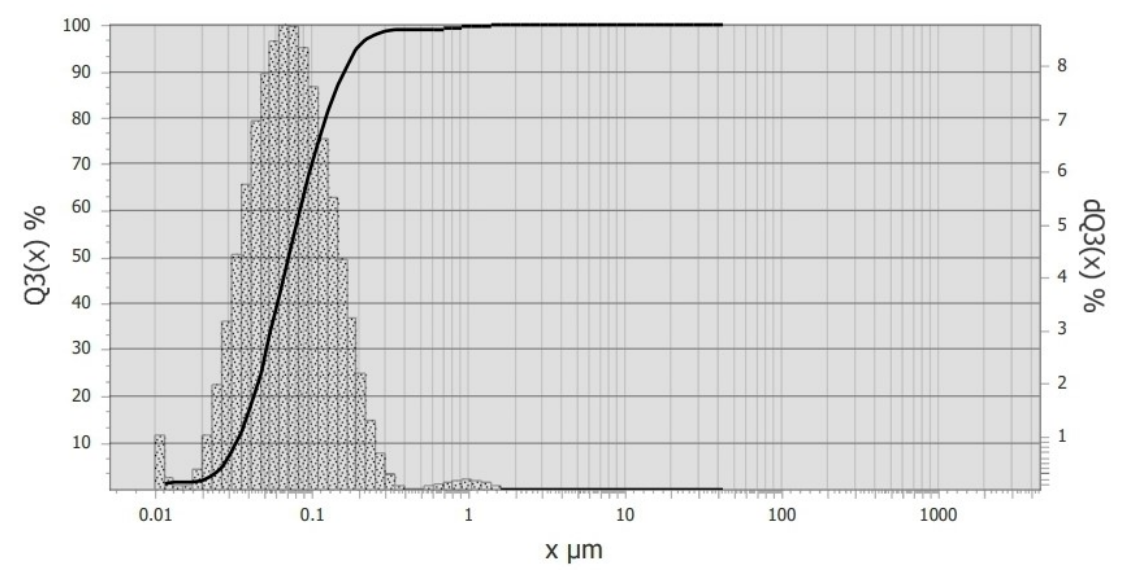

Gambar 4. Grafik Hasil Ukuran Nanokitosan Analysette 22 NanoTec 
Pada penelitian ini rerata diameter zona hambat campuran nanokitosan $1 \%$ dengan ekstrak biji kelengkeng konsentrasi $80 \%, 60 \%$ dan $40 \%$ adalah 9,38 $\pm 0,802 \mathrm{~mm}$, $8,47 \pm 0,690 \mathrm{~mm}$ dan $7,10 \pm 0,978 \mathrm{~mm}$. Sedangkan pada kontrol positif ekstrak biji kelengkeng murni konsentrasi 80\% (9,10 mm), 60\% (7,15 mm) dan konsentrasi 40\% $(6,18 \mathrm{~mm})$. Secara statistik diperoleh adanya perbedaan yang bermakna dari ketiga kelompok sampel dengan derajat kemaknaan $\alpha=5 \%$. Data menunjukkan zona hambat terhadap Staphylococcus aureus semakin besar seiring meningkatnya konsentrasi ekstrak yang diberikan, baik pada campuran maupun ekstrak murni. Penelitian ini sesuai dengan Santi (2011) yang mengatakan ekstrak etanol biji kelengkeng dimana konsentrasi 2\% hingga 8\% menunjukkan peningkatan aktivitas pertumbuhan bakteri Staphylococcus aureus dengan cara merusak permebealitas dinding sel. Penelitian lainnya dilakukan Trisia (2018) terhadap ekstrak daun kalanduyung (Guazuma ulmifolia Lam.) yang mengandung saponin, flavonoid, steroid, tanin dan memiliki kandungan alkaloid yang efektif terhadap bakteri Staphylococcus aureus pada konsentrasi $80 \%$ adalah 14,9 mm, $60 \%$ adalah $10,2 \mathrm{~mm}$ dan $40 \%$ adalah $8,5 \mathrm{~mm}$. Bertambahnya zona hambat tersebut didapat dari peningkatan konsentrasi ekstrak dimana semakin banyak pula kandungan senyawa antibakteri di dalamnya (Alam et al., 2017).

Tabel 2. Diameter zona hambat campuran nanokitosan $1 \%$ dengan ekstrak biji kelengkeng konsentrasi $80 \%, 60 \%, 40 \%$ dalam menghambat pertumbuhan Staphylococcus Aureus

\begin{tabular}{|c|c|c|c|c|c|c|c|c|c|}
\hline \multirow[b]{2}{*}{ Bahan Uji } & \multirow[b]{2}{*}{ Konsentrasi } & \multicolumn{6}{|c|}{ Replikasi (mm) } & \multirow[b]{2}{*}{$\begin{array}{c}\text { Diameter } \\
\text { Mean } \\
(\mathrm{mm})\end{array}$} & \multirow[b]{2}{*}{ SD } \\
\hline & & 1 & 2 & 3 & 4 & 5 & 6 & & \\
\hline \multirow{3}{*}{ Campuran } & $80 \%$ & 8,15 & 10,10 & 10,05 & 9,08 & 10,5 & 8,4 & 9,38 & 0,802 \\
\hline & $60 \%$ & 7,5 & 9,25 & 9,3 & 8,35 & 8,3 & 8,15 & 8,47 & 0,690 \\
\hline & $40 \%$ & 6,23 & 8,43 & 7,28 & 7,2 & 7,2 & 6,3 & 7,10 & 0,978 \\
\hline \multirow{4}{*}{$\begin{array}{c}\text { Kontrol } \\
\text { Positif } \\
\text { Ekstrak biji } \\
\text { kelengkeng }\end{array}$} & $80 \%$ & & & & 9,10 & & & & \\
\hline & & & & & & & & & \\
\hline & $60 \%$ & & & & 7,15 & & & & 0,000 \\
\hline & $40 \%$ & & & & 6,18 & & & & \\
\hline Nanokitosan & $1 \%$ & & & & 9,45 & & & & 0,000 \\
\hline
\end{tabular}

Sumber : Data primer, 2020

Ket $:$ Campuran $=$ nanokitosan $1 \%$ dengan ekstrak biji kelengkeng konsentrasi 80\%,60\%, 40\%

Tabel 3. Hasil uji one way ANOVA

\begin{tabular}{lccc}
\hline \multicolumn{1}{c}{ Bahan uji } & Mean & SD & $p$ value \\
\hline Campuran & & & \\
$80 \%$ & 9,38 & 0,802 & \\
$60 \%$ & 8,47 & 0,690 & \\
$40 \%$ & 7,10 & 0,978 & \multirow{2}{*}{$0,000^{*}$} \\
\hline Kontrol Positif & & & \\
Ekstrak Biji Kelengkeng & & & \\
$80 \%$ & 9,10 & & \\
$60 \%$ & 7,15 & 0,000 & \\
$40 \%$ & 6,18 & & \\
\hline Kitosan 1\% & 9,45 & 0,000 & \\
\hline
\end{tabular}

Sumber : Data primer, 2020

Ket : Campuran = nanokitosan $1 \%$ dengan ekstrak biji kelengkeng konsentrasi 80\%,60\%,40\% * = adanya perbedaan yang signifikan $(\mathrm{p}<0.05)$ 

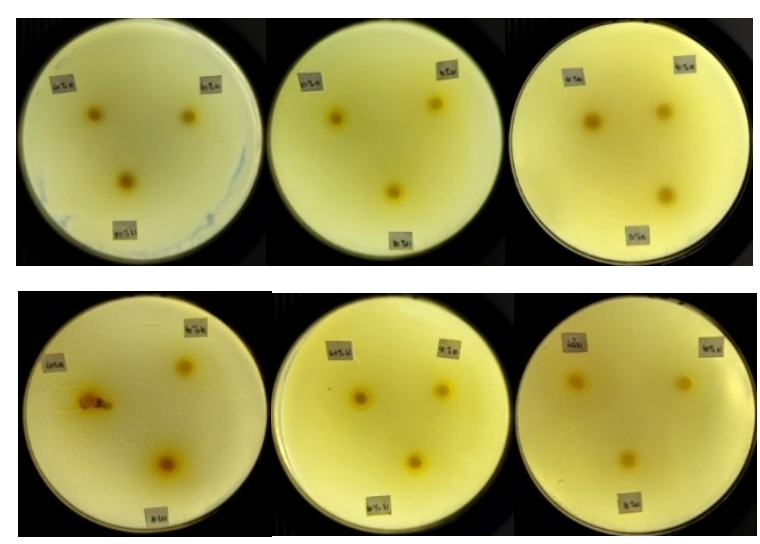

Gambar 5. Hasil uji efektivitas antibakteri Staphylococcus aureus pada campuran nanokitosan $1 \%$ dengan ekstrak biji kelengkeng konsentrasi $80 \%, 60 \%, 40 \%$

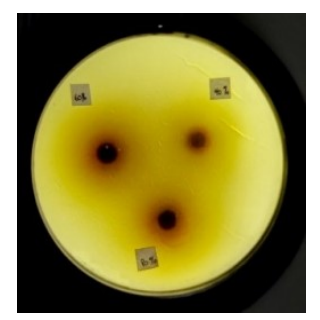

Gambar 6. Hasil uji efektivitas antibakteri Staphylococcus aureus pada kontrol positif ekstrak biji kelengkeng konsentrasi $80 \%, 60 \%, 40 \%$

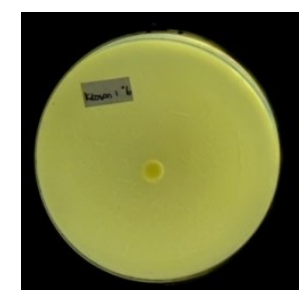

Gambar 7. Hasil uji efektivitas antibakteri Staphylococcus aureus pada kontrol positif kitosan 1\%

Hasil penelitian ini sejalan dan sesuai oleh penelitian Rismana (2014) menyatakan campuran nanokitosan dengan ekstrak kulit buah manggis 1\%-2\% menunjukkan hasil daya hambat yang paling besar. Daripada ekstrak kulit buah manggis, campuran nanokitosan dan ekstrak lebih baik dalam menghambat Propionibacterium acnes. Hal ini dikarenakan fungsi nanokitosan sebagai bahan matriks yang membawa dan menghantarkan senyawa aktif (ekstrak) sehingga aktivitasnya lebih tinggi. Hasil diatas sesuai dengan penelitian Lestari (2018) dimana zona hambat meningkat dari konsentrasi 0,20\%-1,40\% dikarenakan campuran kitosan dengan ekstrak daun kesum yang samasama memiliki kemampuan sebagai antibakteri. Kandungan daun kesum yaitu senyawa golongan fenolik, triterpenoid/steroid, flavonoid, alkaloid dan minyak atsiri yang apabila konsentrasinya semakin tinggi maka mempengaruhi nilai daya hambat terhadap bakteri. 


\section{Simpulan Dan Saran}

Terdapat perbedaan efektivitas antibakteri antara campuran nanokitosan 1\% dengan ekstrak biji kelengkeng (Dimocarpus longan Lour) konsentrasi 80\%, 60\%, 40\% terhadap Staphylococcus aureus, dimana diameter zona hambat paling optimal pada konsentrasi tertinggi dan minimal pada konsentrasi terendah. Demikian juga pada ekstrak murni biji kelengkeng dengan konsentrasi 80\%,60\% dan 40\% terlihat kecenderungan sejenis. Hal ini membuktikan bahwa daya hambat ekstrak biji kelengkeng terhadap bakteri meningkat seiring peningkatan konsentrasi ekstrak.

Penting bagi peneliti selanjutnya untuk membuat beberapa variasi konsentrasi nanokitosan sehingga dapat dianalisa peningkatan zona hambat yang paling optimal, uji konsentrasi bunuh minimum (KBM) ekstrak biji kelengkeng dengan penambahan nanopartikel nanokitosan 1\% terhadap pertumbuhan Staphylococcus aureus, uji daya hambat ekstrak biji kelengkeng dengan penambahan nanokitosan terhadap pertumbuhan bakteri rongga mulut lainnya.

\section{Daftar Rujukan}

Alam, A.N et al. (2017). Penentuan Konsentrasi Minimum Ekstrak Daun Anting-Anting (Acalypha indica L .) Sebagai Antibakteri Pada Staphylococcus Aureus. Unnes Journal of Life Science, 6(1), 34-39.

Apridamayanti, P. et al. (2017). Sensitivitas Bakteri Staphylococcus Aureus Terhadap Antibiotik Terapi Ulkus Diabetikum Derajat III Dan IV Wagner. Seminar Nasional Penerapan Ilmu Pengetahuan Dan Teknologi, 77-83.

Bangun, H. et al. (2018). Preparation and Evaluation of Chitosan-Tripolyphospate Nanoparticles Suspension as an Antibacterial Agent. Journal of Applied Pharmaceutical Science. Journal of Applied Pharmaceutical Science, 8(12), 147156. https://doi.org/10.7324/JAPS.2018.81217

Berger, J. et al. (2004). Structure and Interaction In Covalently and Ionically Crosslinked Chitosan Hydrogels for Biomedical Applications. In European Journal of Pharmaceutics and Biopharmaceutics (pp. 19-34). https://doi.org/10.1016/S0939-6411(03)00161-9

Damayanti, W. et al. (2016). Aplikasi Kitosan Sebagai Antibakteri Pada Filet Patin Selama Penyimpanan Suhu Rendah. 19(3), 321-328. https://doi.org/10.17844/jphpi.2016.19.3.321

Dustgania, A. et al. (2008). Preparation Of Chitosan Nanoparticles Loaded By Dexamethasone Sodium Phosphate. Iranian Journal of Pharmaceutical Sciences, $4(2), 111-114$.

Florenly et al. (2015). The Removal Of Cr(VI) With Dimocarpus longan As a Low Cost Biosorbent. Journal of Chemical and Pharmaceutical Research, 7(9), 81-88.

Florenly et al. (2016). The Effects Of Cr(VI) In The Kidney Of Experimental Rats And Utilization Of Longanpeel Fruit (Dimocarpus longan) As Renal Protector In Dentistry. Der Pharma Chemica, 8(16), 144-148.

Gupta, R. et al. (2006). Nanoparticle Technology for Drug Delivery. In Nanoparticle Technology for Drug Delivery. https://doi.org/10.1201/9780849374555

Herlinawati. (2018). Pengetahuan Tentang Pemeliharaan Kesehatan Gigi Dan Deskripsi Jumlah Karies Gigi Ibu Pekerja Di Kelurahan Tualang Kecamatan Perbaungan Serdang Bedagai. Jurnal Ilmiah PANNMED, 13(2), 121-125.

Lestari, R.B. et al. (2018). Pemanfaatan Kitosan Kulit Udang Dengan Penambahan Ekstrak Daun Kesum Sebagai Penghambat Bakteri Pada Edible Coating. Jurnal Teknologi Pertanian, 19(3), 207-214. https://doi.org/10.21776/ub.jtp.2018.019.03.7 
Lumbessy, M. et al. (2013). Uji Total Flavonoid Pada Beberapa Tanaman Obat Tradisonal Di Desa Waitina Kecamatan Mangoli Timur Kabupaten Kepulauan Sula Provinsi Maluku Utara. Jurnal MIPA, 2(1), 50-55.

https://doi.org/10.35799/jm.2.1.2013.766

Marhamah. (2016). Resistensi Bakteri Gram Positif Terhadap Antibiotik Di UPTD Balai Laboratorium Kesehatan Lampung Tahun 2012-2014. 5(1), 467-474.

Mohanraj, V.J. et al. (2006). Nanoparticles - A review. Tropical Journal of Pharmaceutical Research, 5(1), 561-573. https://doi.org/10.4314/tjpr.v5i1.14634

Ngajow, M. et al. (2013). Pengaruh Antibakteri Ekstrak Kulit Batang Matoa (Pometia Pinnata) Terhadap Bakteri Staphylococcus aureus Secara In Vitro. Jurnal MIPA UNSRAT, 2(2), 128-132. https://doi.org/10.35799/jm.2.2.2013.3121

Nonci, F. et al. (2015). Uji Efektivitas Antibakteri Sari Buah Mengkudu (Morinda citrifolia L) Asal Makassar Pada Daging Sapi. JF FIK UINAM, 3(1), 17-21.

Nugraha, A. et al. (2017). Isolasi, Identifikasi, Uji Aktivitas Senyawa Flavonoid Sebagai Antibakteri Daun Mangga. Indonesian Journal of Chemical Science, 6(2), 91-96.

Panuluh, P. (2019). Potensi Cengkeh (Syzigium Aromaticum) Sebagai Antibakteri Methicillin Resistant Staphylococcus Aureus ( MRSA ). Jurnal Ilmiah Kesehatan Sandi Husada, 10(2), 270-274. https://doi.org/10.35816/jiskh.v10i2.168

Parubak, A. S. (2013). Senyawa Flavonoid Yang Bersifat Antibakteri Dari Akway (Drimys becariana. Gibbs). Jurnal Kimia Universitas Sam Ratulangi, 6(1), 34-37.

Prakash, D. V. S. et al. (2014). Optimization of Physico-Chemical Parameters for the Extraction of Quercetin from Medicinal Herbs. Journal of Life Sciences and Technologies, 2(2), 90-93. https://doi.org/10.12720/jolst.2.2.90-93

Prasad, K. N. et al. (2009). High Pressure Extraction of Corilagin from Longan (Dimocarpus Longan Lour.) Fruit Pericarp. Separation and Purification Technology, 70, 41-45. https://doi.org/10.1016/j.seppur.2009.08.009

Prasetya, 0. S. et al. (2019). Uji Aktivitas Antibakteri Dan Antibiofilm Fraksi Biji Kelengkeng (Euphoria longan Lour. Steud.) Terhadap Staphylococcus Aureus ATCC 6538. Journal of Pharmacey Science Annd Practice, 6(2), 84-90.

Putri, A. I. et al. (2018). Karakterisasi Nanopartikel Kitosan Ekstrak Daun Ubijalar ( Ipomoea batatas L .) Menggunakan Metode Gelasi Ionik. Jurnal Pendidikan Dan Ilmu Kimia, 2(2), 203-207.

Qudsi, D. C. M. et al. (2015). Perbandingan Efektivitas Kitosan (2-Acetamido-2-Deoxy-DGlucopyranose) dan Nano Kitosan terhadap Pertumbuhan Bakteri Enterococcus faecalis secara In Vitro. Majalah Kesehatan FKUB, 2(4), 229-240.

Rachmawati, A. et al. (2018). Formulasi Dan Karakterisasi Nanopartikel Sambungsilang Gom Xantan Dan Gom Akasia Untuk Penghantaran Insulin Oral. Pharmaceutical Sciences and Research, 5(3), 159-168.

Ramadhani, P. et al. (2017). Hambat Ekstrak Etanol Rimpang Kunyit (Curcuma domestica V.) terhadap Pertumbuhan Bakteri Staphylococcus aureus Secara In Vitro. Jurnal Kesehatan Andalas, 6(3), 590-595. https://doi.org/10.25077/jka.v6i3.743

Rangkadilok, N. et al. (2012). In-vitro Antifungal Activities of Longan (Dimocarpus Longan Lour.) Seed extract. Fitoterapia, 83(3), 545-553. https://doi.org/10.1016/j.fitote.2011.12.023

Ripa, F. A. et al. (2010). In-vitro Antibacterial, Cytotoxic and Antioxidant Activities of Plant Nephelium Longan. Pakistan Journal of Biological Sciences, 13, 22-27. https://doi.org/10.3923/pjbs.2010.22.27

Rismana, E. et al. (2014). Pengujian Aktivitas Antiacne Nanopartikel Kitosan-Ekstrak Kulit Buah Manggis (Garcinia Mangostana). Media Penelitian Dan Pengembangan Kesehatan, 24(1), 19-27. https://doi.org/10.22435/mpk.v24i1.3483.19-27

Santi, R. N. et al. (2011). Aktivitas Antibakteri Ekstrak Etanol Kulit Dan Biji Kelengkeng (Euphoria longan (Lour.) Steud) terhadap Escheria coli dan Staphylococcus 
aureus Serta Toksisitasnya Terhadap Artemia salina Leach. Pharmachon, 12(1), 33-39.

Sari, R. et al. (2017). Uji Aktivitas Antibakteri Ekstrak Etanol Daun Gaharu (Aquilaria microcarpa Baill.) Terhadap Bakteri Staphylococcus aureus dan Proteus mirabilis. Pharmaceutical Sciences Research, 4(3), 143-154.

Soong, Y. Y. et al. (2005). Isolation and Structure Elucidation of Phenolic Compounds from Longan (Dimocarpus Longan Lour) Seed by High-Performance Liquid Chromatograpghy-Electrospray Ionization Mass Spectometry. Journal of Chromatography A, 1085, 270-277.

https://doi.org/10.1016/j.chroma.2005.06.042

Soong, Y. Y. et al. (2006). Quantification of Gallic Acid and Ellagic Acid from Longan (Dimocarpus Longan Lour.) Seed and Mango (Mangifera Indica L.) Kernel and Their Effects on Antioxidant Activity. Food Chemistry, 97, 524-530. https://doi.org/10.1016/j.foodchem.2005.05.033

Trisia, A. et al. (2018). Uji Aktivitas Antibakteri Ekstrak Etanol Daun Kalanduyung (Guazuma Ulmifolia Lam.) Terhadap Pertumbuhan Staphylococcus Aureus Dengan Metode Difusi Cakram (Kirby-Bauer). Anterior Jurnal, 17(2), 136-143. https://doi.org/10.33084/anterior.v17i2.12

Tseng, H. C. et al. (2014). Antimcrobial Activties of Various Fraction of Longan (Dimocarpus Longan Lour. Fen Ke) Seed Extract. International Journal of Food Sciences and Nutrition, 65(5), 589-593. https://doi.org/10.3109/09637486.2014.886181

Wau, T. P. K. et al. (2019). Uji Efektivitas Ekstrak Buah Kesemek (Dyospiros Kaki L.) Sebagai Antibakteri Terhadap Bakteri Escheria Coli. Jurnal Biologi Tropis, 19(2), 260-267. https://doi.org/10.29303/jbt.v19i2.1049

Yamin, I. F. et al. (2014). Bakteri Dominan di Dalam Saluran Akar Gigi Nekrosis. Dentofasial, 13(2), 113-116. 